\title{
ESCRITURA AUTOBIOGRÁFICA Y TRAUMAS COLECTIVOS: DE LA EXPERIENCIA PERSONAL AL COMPROMISO UNIVERSAL
}

JAVIER SÁNCHEZ ZAPATERO

Universidad de Salamanca

\section{RESUMEN}

El artículo intenta explicar de qué forma la escritura autobiográfica $-\mathrm{y}$, en concreto, la variantes textual que la crítica literaria ha denominado «testimonio histórico»- puede, en determinados contextos identificados como «traumas colectivos», adquirir un valor cognitivo. Es de prioritario interés estudiar cómo la experiencia personal puede servir en ocasiones de instrumento contra el olvido y la deformación histórica de la memoria de las sociedades.

Palabras clave: Memoria, Autobiografía, Compromiso, Trauma, Teoría de la Literatura.

\section{AUTOBIOGRAPHICAL WRITING AND COLLECTIVE TRAUMAS: FROM PERSONAL EXPERIENCE TO UNIVERSAL CONMMITMENT}

\begin{abstract}
The article studies how it is possible that the autobiographical writing can acquire a cognitive value in some contexts, for example in the «collective traumas». The article analyzes the cases of some writers-witnesses and tries to explain how the personal experience can serve of instrument against the oblivion and the historical deformation of the social memory.
\end{abstract}

Key words: Memory, Autobiography, Commitment, Trauma, Theory of Literature.

\section{LA ESCRITURA DEL TRAUMA}

La escritura autobiográfica cobra especial importancia en momentos de intensidad emocional. Así lo demuestra, por ejemplo, la evidente vinculación que existe entre la composición de textos autobiográficos y la vivencia de etapas caracterizadas por el cambio, como pueden ser la adolescencia o la senectud. Experimentar determinadas situaciones como la maternidad $-\mathrm{y}$, en menor medida, la paternidad-, el desamor o el duelo también parece predisponer a la creación de textos en los que queden plasmadas las vivencias de 
quien observa cómo todo se modifica a su alrededor. Para explicar esta relación, Virgilio Tortosa ha aludido a la «crisis de identidad» ${ }^{1}$ que sufre todo sujeto que, como en las edades y en las fases señaladas, ha de enfrentarse a cambios físicos, responsabilidades hasta entonces desconocidas, nuevos roles sociales, etc. En parecidos términos se ha expresado Anna Caballé, para quien, de hecho, la causa más frecuente de escritura autobiográfica $-\mathrm{y}$ en especial de diarios - se explica «bien por la crisis evolutiva del ser humano, bien por la crisis del medio en que se desenvuelve (...) y con el que colisiona ${ }^{2}$. A estas explicaciones resulta pertinente añadir la consideración de etapa clausurada y finiquitada que todo ciclo vital parece mantener del inmediatamente anterior, permitiendo con ello referirse a él como si de un todo completo se tratase y asemejarlo a la condición existencial. Especialmente perceptible es esta interpretación del tiempo en las autobiografías que se escriben en los últimos años de la vida, cuando el sujeto creador presiente tanto la cercanía de la muerte como la fragilidad de la propia existencia.

De todos los textos que forman lo que se podría denominar el «espectro autobiográfico», es el diario íntimo el modelo que de forma más paradigmática demostraría el valor terapéutico, de fortalecimiento de la propia identidad ante el cambio y de desahogo emocional que puede implicar la escritura. Concebidos para no ser leídos por nadie más que sus propios autores ${ }^{3}$, cons-

${ }^{1}$ TORTOSA, Virgilio. Escrituras ensimismadas. La autobiografía literaria en la democracia española. Alicante: Universidad de Alicante, 1996, p. 184. Una de las razones por las que Tortosa explica la proliferación de textos autobiográficos en las últimas décadas del siglo XX es la constante situación de crisis que vive el sujeto en la edad contemporánea, caracterizada por el desmoronamiento de los grandes proyectos y paradigmas colectivos, los avances científicos y médicos, los cambios introducidos por las nuevas tecnologías en los modos de comunicación, el mestizaje de las sociedades o el cada vez mayor poder de las minorías. Todo ello, según el autor, ha provocado «un cambio del entorno humano (...) diseñado por el hombre hasta el punto de que su verdadero protagonista se halla transformado por los objetos sobre los que ha actuado reiteradamente».

${ }^{2}$ CABALLÉ, Anna. Narcisos de tinta. Ensayo sobre la bibliografía en lengua castellana (siglos XIX y XX). Madrid: Megazul, 1995, p. 55.

${ }^{3}$ Puesto que todo texto, en su condición de mensaje comunicativo, necesita de un receptor para poder ser considerado como tal, la existencia del diario íntimo, concebido en principio para no ser leído, constituye toda una paradoja. Si es leído, pierde una de sus características esenciales, pero si no llega hasta ningún receptor, no puede considerarse que el acto de comunicación literaria se haga efectivo, pues no hay nadie que le otorgue sentido. El escritor polaco-argentino Witold Gombrowicz expuso esta contradicción en un pasaje de su diario —evidentemente, ya publicado-: «¿Para quién escribo? Si es para mí mismo, ¿por qué lo mando a la imprenta? Y si es para el lector, ¿por qué hago como si hablara conmigo mismo? ¿Hablas a ti mismo de tal manera que te oigan los demás?». Antonio Muñoz Molina ha resuelto el aparente dilema de forma expeditiva al afirmar que «miente quien dice no escribir para nadie, quien dice hacerlo solo para su solo placer o suplicio», mientras que Philippe Lejeune ha defendido el estatuto de acto de comunicación del diario aunque no sea leído por nadie al sostener que «todo diario tiene un destinatario, aunque éste sea uno mismo» (Vid. GOMBROWICZ, Witold. Diarios (1953-1969). Barcelona: Seix-Barral, 2001, p. 69; MUÑOZ MOLINA, 
tituyen, según ha apuntado Manuel Alberca, «la búsqueda o el logro de un equilibrio siempre en trance de ser alcanzado o perdido (...) y es evidente que su principal función, aunque no única, es la de intentar sostener la identidad personal que corre el riesgo de derrumbarse ${ }^{4}$.

Además de los momentos críticos, también las experiencias traumáticas pueden convertirse en estímulos generadores de obras en las que el autor dé cuenta de lo vivido. En el ámbito de la Psicología, se considera trauma psíquico a todo choque emocional que deja huella en el subconsciente de quien lo sufre. El término — cuyo significado originario es el de «herida»— comenzó a ser utilizado de forma sistemática en el ámbito de la investigación científica en los estudios en los que Sigmund Freud analizaba los trastornos psíquicos que podía sufrir una persona como consecuencia de un acontecimiento negativo para su evolución psicológica natural. Todo trauma, por tanto, nace de una experiencia suficientemente impactante como para dejar huella en quien la ha vivido. Es en la infancia y en la adolescencia cuando mayor puede ser su capacidad de influencia, debido a que la personalidad aún no se ha configurado por completo y a que la capacidad de enfrentarse al conflicto es menor. Teniendo en cuenta que la noción de trauma mantiene como rasgos definitorios su «singularidad única» ${ }^{5}$ y su carácter inesperado y excepcional — «en la medida que lo traumático es algo con lo que nadie contaba» ${ }^{6}$-, parece lógico aceptar que son las edades en las que menor conocimiento y experiencia se posee las más proclives a sufrirlo.

El impacto generado por la emoción de participar, como víctima o como mero espectador, en un acontecimiento traumático puede tener diversas y variadas consecuencias en la memoria, pues «en ocasiones [los traumas] producen recuerdos excelentes (...) o son recuperados excesivamente (...) y, por el contrario, otras veces no se recuerdan en absoluto» ${ }^{7}$. La tensión a la que se ven sometidos quienes están presentes en el desarrollo de un acontecimiento caracterizado por su elevado nivel de dramatismo e intensidad provoca estos desajustes e irregularidades en el proceso de formación y conservación de los recuerdos ${ }^{8}$.

\footnotetext{
Antonio. Diario del Nautilus. Madrid: Debolsillo, 2002, p. 1984; LEJEUNE, Philippe. El pacto autobiográfico y otros estudios. Madrid: Megazul, 1994, p. 169).

${ }^{4}$ ALBERCA, Manuel. La escritura invisible. Testimonios sobre el diario íntimo. Madrid: Sendoa, 2000, p. 32.

${ }^{5}$ TODOROV, Tzvetan. Los abusos de la memoria. Barcelona: Paidós, 2000, p. 37.

${ }^{6}$ CRUZ, Manuel. Las malas pasadas del pasado. Barcelona: Anagrama, 2005, p. 190.

${ }^{7}$ RUIZ-VARGAS, José María. «Claves de la memoria autobiográfica». En: Hermosilla Álvarez, M Mángeles; Fernández Prieto, Celia (eds.). Autobiografía en España, un balance: actas del congreso internacional celebrado en la Facultad de Filosofía y Letras de Córdoba del 25 al 27 de octubre de 2001. Madrid: Visor, 2004, pp. 183-222.

${ }^{8}$ La noción de recuerdo traumático ha sido definida como «el resultado de una experiencia catastrófica, arrolladora, que sobrepasa la fuerza psíquica e, incluso, física, de un individuo» en DUPLÁÁ, Christina. Memoria sí, venganza no, en Josefina Aldecoa. Barcelona: Icaria, 2000, p. 39.
} 
Sin embargo, a pesar de que hay casos en los que sufrir un trauma conlleva un olvido absoluto, provocado bien por una amnesia inducida, bien por un mecanismo represivo de autodefensa, la longevidad y fidelidad son las principales características de los recuerdos de lo que puede ser considerado como «experiencias límite»:

La memoria de los testigos presenciales de los sucesos emocionalmente negativos ha demostrado ser muy precisa, sobre todo tras intervalos de retención largos —no inmediatos-. Por otro lado, los recuerdos fotográficos resultan ser muy consistentes (...), así como excepcionalmente claros, ricos en detalles y asombrosamente resistentes al olvido y al paso del tiempo. Por último, las experiencias traumáticas parecen ir asociadas a evocaciones dolorosamente vívidas que han demostrado ser muy exactas e inmunes al olvido?

En muchos casos, un acontecimiento traumático puede convertirse en hecho generador de la escritura, que puede adoptar un valor catártico ${ }^{10}$ para quien lo ha sufrido. Para quien ha sido testigo de situaciones convulsas, rememorar puede convertirse en una especie de terapia con la que liberar e intentar asimilar todo lo vivido. De hecho, Jean François Chiantaretto ${ }^{11}$ ha llegado a afirmar que los textos autobiográficos admiten una lectura desde prismas psicoanalíticos y, como tal, pueden convertirse en elementos al servicio de la cura de un sujeto cuya identidad se muestra escindida o sometida a continuas crisis $^{12}$. De todos modos, se ha de tener en cuenta que la «concepción terapeútica y liberadora» de la escritura autobiográfica no es privativa de los textos que se refieren a la vivencia de acontecimientos traumáticos. Albert Boadella, por ejemplo, comentó que la escritura de su libro Memorias de un bufón «desde el punto de vista de la sinceridad, del dolor [que le] había supuesto contar algunas cosas y de la terapia resultante, [para él] había sido extraordinariamente positiva» ${ }^{13}$.

Según Angelina Muñiz-Huberman, el testimonio adquiere una función catártica en la medida en que permite afianzarse al individuo en absoluta soledad y sólo con la esencia de su ser:

${ }^{9}$ RUIZ-VARGAS, José María. Op. cit., p. 1984.

${ }^{10}$ La interpretación de la obra literaria como elemento catártico está ya presente en la teoría aristotélica, aunque en ella se vincula de forma exclusiva la función liberadora del arte con el género de la tragedia. Superada esa identificación, el hombre interpreta la literatura como una forma de liberación y superación de elementos existenciales adversos y dolorosos, como una búsqueda de paz y armonía íntimas.

${ }^{11}$ CHIANTARETTO, Jean François. De l'acte autobiographique. París: Champ Vallon, 1995, pp. 24-42.

${ }^{12}$ No en vano, desde los estudios fundacionales de Freud -interesados tanto en el origen de los temas sobre los que escriben los autores como por la interpretación de la literatura como reflejo de deseos, recuerdos y traumas del pasado — ha sido la crítica psicoanalítica la que más se ha preocupado por analizar su impacto en la creación literaria y su articulación en el lenguaje.

${ }^{13}$ BOADELLA, Albert. «Autobiografía y psicoanálisis gratuito». En: Hermosilla Álvarez, M. ${ }^{a}$ Ángeles; Fernández Prieto, Celia (eds.). Op. cit., p. 79. 
Es la confesión un acto irrepetible, total, absoluto, directo, real, sin adornos. Es la escueta verdad y la imposibilidad del arrepentimiento. Es una huida de sí, un vaciamiento, pero es también un deseo de sostén y de apoyo, de aclaración de los hechos, de búsqueda de sentido. Representa la máxima acción que es dado ejecutar con la palabra. (...) Quien se confiesa arranca de una desesperación que anhela ser curada. Quien se ha cansado de sí mismo y vaga perdido por el mundo necesita expresar su huida para conjurarla y al mismo tiempo para dejar constancia ${ }^{14}$.

Quien ha sufrido una vivencia traumática siente la necesidad de narrarla a los demás para poder intentar dotarla de sentido a través de su propio relato. Los internados en campos de concentración, por ejemplo, han insistido en que las dos necesidades básicas que habían de cumplimentar para sobrevivir a su encierro eran comer y contar. La obsesión de recordar y narrar está presente en prácticamente todas las obras del corpus concentracionario, hasta el punto de que el mero acto comunicativo en el campo suponía una de las únicas formas que tenían los internados de abstraerse del opresivo clima en el que se encontraban. La búsqueda de un receptor atento marca todo su periplo presidiario que, una vez terminado, sigue ansiando «un oído incansable y mortal para las voces de la muerte» ${ }^{15} \mathrm{o}$ «un deseo frenético de contar [la experiencia en los campos] con pelos y señales» ${ }^{16}$. Esta dimensión catártica de la escritura hizo que Georges Perec (1992: 174) llegase a afirmar que relatar lo sucedido se convirtió en una necesidad para los supervivientes:

Hablar, escribir son, para el deportado que regresa, una necesidad tan inmediata y perentoria como su necesidad de calcio, azúcar, sol, carne, sueño, silencio. No es cierto que pueda callar y olvidar. Primero tiene que recordar. Tiene que dominar ese mundo del que fue víctima ${ }^{17}$.

El relato vivencial de los internados no sólo contribuyó a asimilar lo ocurrido una vez hubo finalizado, sino que, además, ayudó a soportar las duras condiciones de vida de los espacios concentracionarios, tal y como expresó Jorge Semprún en una de sus obras sobre su experiencia como prisionero en el campo de Buchemwald:

Me senté al lado de aquel desconocido de mi edad. Le hablé, parecía escucharme. La hablé de la lejana noche de la llegada a Buchenwald, la noche de nuestra llegada, juntos. Aunque su capacidad de escuchar, de prestar atención, de comprender, estaba mermada, embotada, por el abandono físico y espiritual, yo quería reavivar en él la chispa de la conciencia propia, de la memoria personal. Sólo podría interesarse de nuevo por el mundo si conseguía interesarse por sí mismo, por su propia historia. Hablé durante mucho rato, él me escuchaba (...). Yo le

${ }^{14}$ MUÑIZ-HUBERMAN, Angelina. «María Zambrano y el concepto de exilio». En: Manuel Aznar Soler (ed.). Las literaturas del exilio republicano español. Bellatera: Gexel - Associació d'Idées, 2003, p. 106.

${ }^{15}$ SEMPRÚN, Jorge. La escritura o la vida. Tusquets: Barcelona, 2002, p. 173.

${ }^{16}$ ANTELME, Robert. La especie humana. Madrid: Arena, 2001, p. 64.

${ }^{17}$ PEREC, Georges. L. G. Une aventure des années soixante. París: Seuil, 1992, p. 174. 


\begin{abstract}
pagaba tabaco para que él me escuchase contarle la vida. A partir de entonces ya no hice nada más: mi vida de antes y la de Buchemwald, mezcladas, entrecruzadas. También mis sueños. Los de antes, obsesivos — «el asalto bajo el sol de los cuerpos de mujeres»- y los de Buchemwald, enfangados en la inasible y viscosa presencia de la muerte. Nadie sabrá medir objetivamente hasta qué punto esta cura fue benéfica para mí. Yo más bien tiendo a no dudarlo ${ }^{18}$.
\end{abstract}

$\mathrm{Al}$ adquirir la escritura para los supervivientes un valor liberador, relatar lo sucedido o reflexionar sobre ello se puede convertir en uno de los pocos medios de que se dispone para intentar asimilar una experiencia marcada por un nivel de horror tan elevado como incomprensible. Como ha señalado Francisco Caudet, «si narrar — que es una forma, como otras muchas, de actuarno cura el dolor, al menos lo alivia ${ }^{19}$. Max Aub fue consciente de la importancia del testimonio literario como acto consolatorio al indicar que «en la desgracia lo importante es el recuerdo, [porque] el recuerdo lo vence todo, la alegría, la desgracia ${ }^{20}$. Análogas reflexiones efectuó Primo Levi, quien destacó el valor de estímulo y de liberación de la narración vivencial al afirmar que «si no hubiera vivido la temporada en Auschwitz, es probable que nunca hubiera escrito nada $»^{21}$. La experiencia del intelectual italiano pone de manifiesto cómo después de vivir una situación extrema la escritura se convierte en un elemento catártico y liberador, como evidencia el hecho de que muchos de los textos escritos por supervivientes de guerra, de procesos carcelarios o de cualquier tipo de acontecimientos traumáticos estén escritos por personas sin experiencia literaria alguna. El propio caso de Levi, químico de profesión y sin obra anterior a la II Guerra Mundial, es buen ejemplo de ello:

Escribía porque sentía la necesidad de hacerlo. [Si me preguntan] que vaya más allá, que encuentre dónde nace esta necesidad, no sabría contestarles. Tenía la impresión de que el acto de escribir equivalía para mí a tenderme en el diván de Freud. Sentía una necesidad tan imperiosa de contar, que contaba a viva voz. (...) La intención de «dejar un testimonio» surgió después, escribir como una forma de liberación fue la necesidad primera ${ }^{22}$.

Que la escritura puede responder al hecho de no poder quedar en silencio ante una vivencia que para poder ser asimilada necesita de la continua reflexión sobre ella lo ponen de manifiesto varios de los autores obligados durante el siglo XX a convivir con el horror, la violencia y la muerte. No sólo lo demuestran los casos hasta ahora citados, circunscritos al drama de los

${ }^{18}$ SEMPRÚN, Jorge. Viviré con su nombre, morirá con el mío. Barcelona: Quinteto, 2002, pp. 59-61.

${ }^{19}$ CAUDET, Francisco. «Introducción biográfica y crítica». En Max Aub. Campo de los almendros. Madrid: Castalia, 2000, p. 25.

${ }^{20}$ AUB, Max. Nuevos diarios inéditos (1939-1972). Sevilla: Renacimiento, 2003, p. 117.

${ }^{21}$ LEVI, Primo. Trilogía de Auschwitz. Barcelona: El Aleph, 2005, p. 244.

${ }^{22}$ CAMON, Ferdinando. Primo Levi en diálogo con Ferdinando Camon. Salamanca: Anaya \& Mario Muchnick, 1996, pp. 86-88. 
campos de concentración - $-y$, en el caso de Aub, además, al de una vida peregrina marcada por la intolerancia y la incomprensión-. También lo evidencian ejemplos como los protagonizados por los exiliados. Recuérdese, en ese sentido, que la obra fundacional de la literatura del exilio - Tristes, de Ovidio- era, en esencia, un texto autobiográfico en el que el poeta romano daba cuenta de su situación. Del mismo modo, emblemáticos casos de autores desterrados inscritos en la tradición de la literatura española - Antonio Alcalá Galiano, autor de Recuerdos de un anciano, o José María Blanco White, creador de Vida del reverendo Blanco White, compuesta originalmente en inglés - exponen la intrínseca relación que existe entre la condición de exiliado y la escritura autobiográfica. En el caso de la diáspora republicana española, la prolijidad de testimonios — compuestos para dar sentido a una situación de desintegración personal y para luchar contra la interpretación de la historia efectuada desde el franquismo - vendría demostrada gracias a obras como Recuerdos y olvidos - de Francisco Ayala-, Desde el amanecer. Autobiografía de mis primeros años —de Rosa Chacel—, Vida en claro — de José Moreno Villa_, Memorabilia — de Juan Gil Albert-, Doble esplendor — de Constancia de la Mora-, Los pasos perdidos — de Corpus Barga—, La arboleda perdida — de Rafael Alberti- o Memoria de la melancolía —de María Teresa León-... Intelectuales exiliados en el contexto de la literatura europea del siglo XX, como Stefan Zweig, Vladimir Nabokov y Klauss Mann, también dejaron constancia de su trayectoria vital en El mundo de ayer. Memorias de un europeo, Habla, memoria y Cambio de rumbo.

Otro caso que demuestra la vinculación entre trauma y autobiografía es el del médico Michihiko Hachiya, autor de Diario de Hiroshima, uno de los textos que con más rigor reconstruye, basándose en vivencias propias, lo ocurrido en la ciudad japonesa tras la explosión de la bomba atómica en 1945. Sólo después de la catástrofe se planteó Hachiya la necesidad de escribir un diario, consciente no sólo de estar ante un acontecimiento novedoso y sorprendente por su inmensa capacidad de destrucción, sino también de ver sus asideros vitales tambalearse y de necesitar reflexionar sobre «una destrucción que no podía ser obra de hombres» y «un miedo nunca manifestado como hasta entonces» ${ }^{23}$. La legendaria tradición de textos de memorias de combatientes - muchas veces anónimos- de conflictos bélicos es otro de los casos en los que se demuestra la capacidad de estímulo para la creación literaria que tienen los fenómenos extremos ${ }^{24}$.

${ }^{23}$ HACHIYA, Michihiko. Diario de Hiroshima de un médico japonés (6 de agosto-30 de septiembre de 1945). Barcelona: Turner, 2005, pp. 74 y 92.

${ }^{24}$ Diferente fue el caso de escritores como Ernest Hemingway y André Malraux, catalogados tradicionalmente como «hombres de acción», que tenían en la guerra - $y$, en general, en las situaciones conflictivas - su más potente droga literaria, pues ambos sentían una necesidad carnal e intelectual de «ver la historia de cerca» para escribir. Sus periplos vitales y sus obras literarias ejemplifican esta atracción por las «experiencias límite». Hemingway 
La intrínseca relación que mantienen muchas de las experiencias traumáticas apuntadas con la muerte puede explicar la vinculación con la escritura sobre uno mismo. No en vano, «tal vez sea la muerte el máximo y extremo proceso de crisis que se puede encontrar, y así es como el final de la vida, su límite, se convierte en el tema sobre el que se irá construyendo la producción autobiográfica ${ }^{25}$. Para Jean Molino, «la urgencia del retorno sobre sí mismo [en situaciones críticas y traumáticas] puede manifestarse (...) a causa de una crisis que le hace tomar a uno conciencia de su fragilidad y le induce a interrogarse sobre el balance y el sentido de la propia existencia» ${ }^{26}$. Dado que la muerte implica el paulatino olvido de la existencia, relatar la propia vida se convierte en una forma de luchar contra ella y su poder aniquilador. Desde este punto de vista, se puede entender por qué May defiende que «son muchas las autobiografías que se presentan como tentativas desesperadas de triunfar sobre el tiempo y la muerte» ${ }^{27}$, como se puede comprobar observando el gran número de textos memoriales que se escriben en la senectud, cuando se toma conciencia de la inminencia e insolubilidad de la muerte. Francisco González Ledesma ha evidenciado en las páginas preliminares de su libro de memorias Historia de mis calles cómo la escritura sobre uno mismo y sus vivencias puede ser una forma de lucha contra el paso del tiempo y el inevitable efecto del olvido - con ello, puede convertirse en una escritura que fomente el recuerdo y el conocimiento de lo que tiende a desaparecer-:

Dudas, vas por las calles, te hundes en el metro, miras los viejos árboles que conociste de niño y piensas que todos los días mueren testigos del mundo que tú has visto, y que ese mundo que tú has visto desaparecerá para siempre para ellos. Nadie lo va a recuperar. La gente que tú amaste o en la cual creíste, las mujeres a las que has visto sufrir, los héroes de los que ya nadie habla, los fantasmas que

participó en la I Guerra Mundial, combatiendo como voluntario en el frente italiano, experiencia que serviría años después de base a su novela Adiós a las armas, y también vivió en directo la Guerra Civil Española, a la que acudió en calidad de periodista - como haría años más tarde en la II Guerra Mundial- y de guionista del documental La Tierra Española. El conflicto español inspiró su obra de teatro La quinta columna, su relato La mariposa y el tanque y su celebérrima novela Por quién doblan las campanas. André Malraux, por su parte, vivió la liberación indochina —en la que mantuvo un importante papel como líder de opinión a través de la dirección del periódico L'Indochine - , la revolución china — contexto histórico en el que se ambienta su novela La condición humana-, la Guerra Civil Española —en la que participó activamente como líder de la escuadrilla aérea «España», cuyas vicisitudes fueron narradas en La Esperanza y en la película Sierra de Teruel-y, por último y desde la resistencia francesa, la II Guerra Mundial.

${ }^{25}$ PUERTAS, Ernesto. La escritura autobiográfica en el fin del siglo XIX: el ciclo novelístico de Pío Cid considerado como la autoficción de Ángel Ganivet [tesis doctoral dirigida por José Romera Castillo]. Logroño: Universidad de la Rioja, 2003, p. 373.

${ }^{26}$ MOLINO, Jean. «Interpretar la autobiografía». En Lara Pozuelo (ed.). La autobiografía en lengua española en el siglo XX. Laussane: Hispanica Helvética, 1991, p. 110.

${ }^{27}$ MAY, Georges. La autobiografía. México D. F.: Fondo de Cultura Económica, 1982, p. 60 . 
han dado sentido a tu ciudad y los amigos inocentes de las calles -incluidos los pájaros y los perros-, será como si no hubieran existido nunca. «Venga, tú puedes hacer que no existan», te siguen diciendo (...). Al final he pensado que es verdad, (...) que todos los días muere un pedazo de todos nosotros (...). De modo que aquí comparezco ante ustedes para escribir mis memorias ${ }^{28}$.

En ocasiones, la relación de los acontecimientos traumáticos con la muerte no reside tanto en la posibilidad de convivir con ésta y de intuir su cercanía, sino en la adquisición de una nueva identidad por parte de quien los ha sufrido. Concebir la vivencia de un trauma con el final abrupto de un ciclo vital implica entenderlo como si de una «muerte en vida» se tratase, con lo que la existencia anterior es vista como un todo completo. Consecuentemente, la creación de una nueva identidad permite mirar desde un prisma diferente, el que constituyen la distancia y el cambio, a la antigua. Rene Käes ha explicado que cuando un individuo sufre un trauma externo - o, como se denomina en sus trabajos, una «ruptura psíquica catastrófica»- el daño sufrido es doble, pues afecta tanto a su propio desarrollo personal como a su sentido de pertenencia grupal ${ }^{29}$. De ahí que, consciente de la ruptura de la continuidad personal y social que suponen, W. G. Sebald denominase «mito de la hora cero» ${ }^{30}$ a los acontecimientos dramáticos.

\section{El VALOR COGNITIVO Y ÉTICO DEL TESTIMONIO}

Las vidas de los supervivientes parecen concebidas para ser contadas, no sólo por su deseo de trascender el pasado traumático, sino también por la posibilidad de mostrar a través de la propia experiencia su versión de los hechos y asumir así como tarea vital la defensa de la memoria de un tiempo condenado al olvido o a la deformación histórica:

[Hay que] constatar la necesidad individual —que de forma instintiva surge en quien ha vivido en unas condiciones extremas - de desahogarse y contar lo que ha vivido, con la intención (...) de que se preserve la memoria de lo que ha sufrido y ello prevenga la repetición de sucesos que tienen que ver con la intolerancia, la intransigencia y el totalitarismo ${ }^{31}$.

En su condición de víctimas, los autores son conscientes de que la suma de sus relatos testimoniales puede ser un instrumento al servicio de la lucha política y del cambio social al oponerse a la visión «oficial» de la historia efec-

${ }^{28}$ GONZÁLEZ LEDESMA, Francisco. Historia de mis calles. Barcelona: Planeta, 2006, pp. 10-11.

${ }^{29}$ Vid. KÄES, Rene. Crisis, ruptura y superación. Madrid: Cinco, 1988, pp. 12-39.

${ }^{30}$ SEBALD, W. G. Sobre la historia natural de la destrucción. Barcelona: Anagrama, 2003, p. 37.

${ }^{31}$ PUERTAS, Ernesto. Op. cit., p. 366. 
tuada desde el poder. No en vano, la dimensión del trauma, acostumbra a ser doble, pues no sólo afecta al desarrollo personal sino también al grupal, modificando abruptamente las estructuras de la memoria colectiva que configuran la identidad de un grupo. Aróstegui ha puesto de manifiesto la vinculación existente entre la historia $-\mathrm{y}$, en concreto, la historia del siglo $\mathrm{xX}-\mathrm{y}$ la noción de trauma, al estar dominada por «el dolor, la represión y la tragedia $»^{32}$. Guerras, exilios y persecuciones han sido constantes a lo largo de la evolución del mundo, pero la capacidad técnica y científica alcanzada durante las últimas décadas elevó su dramatismo y potencial destructivo ${ }^{33}$. Los enfrentamientos bélicos —nacionales e internacionales- que salpicaron la historia del siglo pasado condicionaron con su carácter dialéctico y bipolar la creación de dos grupos claramente diferenciados de vencedores y derrotados, unidos por el hecho de que la configuración de ambos estaba condicionada por un hecho traumático:

El sentido del trauma colectivo tiene contenido diverso según se contemple desde el lado de los vencedores o de los vencidos, de los herederos políticos e ideológicos de unos y otros. (...) El trauma, como ruptura fundadora, es percibido y experimentado por el conjunto social ${ }^{34}$.

Como ha afirmado Michael Richards, «la memoria - colectiva e individual- es siempre inherente al cambio social» ${ }^{35}$ que implica todo acontecimiento traumático. La tendencia a presentar los conflictos de forma simplificada y maniquea provoca que, como ha señalado Alain Finkielkraut, aparezcan de forma muy clara dos polos opuestos: vencedores y vencidos, opresores y oprimidos, verdugos y víctimas ${ }^{36}$. El hecho de que uno de esos grupos controle de forma sistemática la información, y con ella la interpretación histórica, convierte a la memoria del otro en «imperativo moral», pues sólo a través de ella se puede establecer una visión global de lo ocurrido. Como ha señalado Milan Kundera (2003: 10), «la lucha del hombre contra el poder es la lucha de la memoria contra el olvido» ${ }^{37}$. El legendario proverbio africano que sostiene que «hasta que los leones tengan sus propios historiadores, las

${ }^{32}$ ARÓSTEGUI, Julio. «Traumas colectivos y memorias generacionales: el caso de la guerra civil». En Aróstegui, Julio; Godicheau, Pierre (eds.). Guerra civil. Mito y memoria. Madrid: Marcial Pons, 2006, pp. 57-92.

${ }^{33}$ En CRUZ, Manuel. Op. cit., pp. 189-191, se ha señalado la paradoja que ha supuesto el hecho de que el trauma, caracterizado por ser una experiencia que trastoca a quien la sufre precisamente por — entre otras cosas - su carácter inesperado, se haya convertido en el siglo XX en una constante de la historia.

${ }^{34}$ ARÓSTEGUI, Julio. Op. cit., p. 65.

35 RICHARDS, Michael. «El régimen de Franco y la política de memoria de la guerra civil española». En Aróstegui, Julio; Godicheau, Pierre (eds.). Op. cit., p. 174.

${ }^{36}$ FINKIELKRAUT, Alain. El judio imaginario. Barcelona: Anagrama, 1990, pp. 9-34.

${ }^{37}$ KUNDERA, Milan. El libro de la risa y el olvido. Barcelona: Seix-Barral, 2003, p. 10 
historias de cacería seguirán glorificando al cazador» evidencia a la perfección la obligación de toda víctima de aportar su punto de vista de la historia para impedir que éste sea deformado o, directamente, eliminado ${ }^{38}$ :

Para los perdedores, la guerra [o cualquier otro acontecimiento traumático] significa una total convulsión del imaginario político e ideológico en y sobre el que se proyectaba [su] experiencia (...); pero para quienes celebran la victoria representa la oportunidad de escribir una historia acorde a sus necesidades y a los infinitos presentes desde la que se irá leyendo hasta que la memoria colectiva dé paso a la memoria histórica ${ }^{39}$.

Según Ricoeur ${ }^{40}$, es consecuencia de esta apropiación y configuración partidista la aparición de tres niveles dentro de la dimensión social de la memoria. Así, es posible hablar de «memoria impedida» — compuesta por los conocimientos y símbolos que no pueden llegar a la sociedad-, de «memoria manipulada» - formada por aquellos acontecimientos del pasado cuya interpretación es voluntariamente deformada - y de «memoria obligada» —integrada por los elementos que se transmiten de forma sistemática y en ocasiones obsesiva a la ciudadanía-.

Por tanto, en la medida en la que algunos traumas colectivos conllevan con frecuencia una modificación absoluta en los parámetros de ordenación de la sociedad en la que se producen y, con ello, una alteración de los filtros que condicionan las estructuras sociales de la memoria, la escritura del trauma puede adquirir una función cognitiva.

Según López de la Vieja, «las experiencias del sufrimiento no forman parte de las crónicas al uso» ${ }^{41}$. En consecuencia, quien ha sido testigo - y víctimade la barbarie, de la intolerancia, de la violencia o del horror y ha comprobado cómo su dolor ha sido ignorado al mismo tiempo que la intolerancia con la que se le trató ha sido legitimada hace de su testimonio - y del relato de la verdad de los hechos que incluye - un elemento a favor del conocimiento y de la ética. Por eso, como ha evidenciado Alicia Molero, «en épocas de conflictividad social y política [la autobiografía] se constituye en un documento de acreditación ${ }^{42}$. La importancia documental de los textos autobiográficos llevó a Ken Plummer (1989) a denominarlos «historias de vida» o «do-

${ }^{38}$ Concebir la interpretación del pasado como si de una auténtica lucha se tratase es una idea recurrente en la obra de Walter Benjamin, para quien la constante pugna entre vencedores y vencidos por alzar su voz y dar a conocer su versión de los hechos es la principal característica de la construcción de la memoria cultural del siglo XX.

${ }^{39}$ DUPLÁA, Christina. Op. cit., p. 42.

${ }^{40}$ RICOEUR, Paul. La memoria, la historia, el olvido. México D. F.: Fondo de Cultura Económica, 2004.

${ }^{41}$ LÓPEZ DE LA VIEJA, María Teresa. Ética y Literatura. Tecnos: Madrid, 2003, p. 106.

${ }^{42}$ MOLERO, Alicia. La autoficción en España. Jorge Semprún, Carlos Barral, Luis Goytisolo, Enrique Antolín y Antonio Muñoz, Molina. Berna: Peter Lang, 2000, p. 63. 
cumentos personales» ${ }^{43}$, equiparándolos así con otras fuentes de información sobre el pasado.

El valor de algunos textos autobiográficos como elementos al servicio del conocimiento del pasado obliga a distinguir entre las diferentes motivaciones que pueden llevar a alguien a la lectura entre la atracción por la figura que va a hablar de sí mismo, el disfrute estético o el interés por un periodo o acontecimiento pretéritos. La primera de las razones citadas se activaría en los casos en los que la vida del «autobiografiado» tiene algún tipo de particularidad que la distingue de las demás y la hace susceptible de ser admirada - o, al menos, de despertar curiosidad-. Los textos confesionales de San Agustín o de Santa Teresa, por ejemplo, pertenecerían a este grupo, así como toda la tradición religiosa en la que se inscriben, por cuanto presentan una vida ejemplarizante en la que los demás pueden encontrar modelos de comportamiento. Del mismo modo, cualquier autobiografía en la que se desgrane el periplo vital de una personalidad pública — conocida por su labor política, artística, deportiva, cultural, etc. - muestra la excepcionalidad de alguien que por sus trayectoria y acciones ha logrado ser distinguido del resto de la sociedad. La segunda de las causas, al hacer referencia al goce estético, parece identificarse con la que motiva la lectura de las autobiografías de los escritores profesionales, en la que no sólo se busca saciar la lógica curiosidad que despiertan los personajes públicos, sino también disfrutar de los aspectos formales de la escritura ${ }^{44}$. Para Jean-Pierre Carron, tal disfrute no ha de implicar ninguna diferencia en la forma de recibir los datos de la vida del personaje en cuestión, por lo que «no parece concebible admitir que la autobiografía de De Gaulle revele más de sí mismo que la Carta al padre de Kafka» ${ }^{45}$. Por último, cuando lo que induce a leer un texto autobiográfico en cualquiera de sus variantes es el deseo de conocimiento de un contexto o un suceso determinados, el autor importa sólo en la medida que ha vivido una época, ha pre-

${ }^{43}$ Vid. PLUMMER, Ken. Los documentos personales: introducción a los problemas y la bibliografía del método humanista. Madrid: Siglo XXI, 1989.

${ }^{44}$ Jordi Gracia ha explicado gráficamente esta doble dimensión de la lectura de los textos autobiográficos de escritores: «¿Releemos a Pavese y el Oficio de vivir para recordar un poco mejor las vísperas de su suicidio? ¿Acudimos a los Diarios de Jünger por segunda vez para recuperar el abstruso nombre de alguno de los bichos que le gustaba cazar? Incluso, cuando regresamos al Josep Pla de Notes diperses, ¿lo hacemos para verificar un dato sobre una lectura o el rastro que ha dejado la visita de alguien al Mas? Es posible que muchos de los lectores regresemos a esos libros con el honesto fin de abastecernos de una información perdida u olvidada, pero me parece que no sabremos callar tampoco la verdad de un efecto estético, estrictamente literario, en la lectura de las obras citadas de esos escritores. Poco se parece la relectura de un libro para rescatar un dato a la relectura que aspira a resucitar, a revivir, el efecto de una obra literaria» (GRACIA, Jordi. «La voz literaria y la materia del dietarista». En: Hermosilla Álvarez, $\mathrm{M}^{\mathrm{a}}$ Ángeles; Fernández Prieto, Celia (eds.). Op. cit., p. 226).

${ }^{45}$ CARRON, Jean-Pierre. Écriture et identité. Pour une poétique de l'autobiographie. París: Ousia, 2002, p. 25. 
senciado un acontecimiento o ha pasado por una experiencia sobre la que se quiere indagar. No interesa su personalidad, ni su forma de poner por escrito los recuerdos, sino, fundamentalmente, su condición de testigo. Así ocurre, por ejemplo, en las crónicas indianas. Textos como Historia verdadera de la conquista de Nueva España o Naufragios son leídos por la información que proporcionan del entonces considerado como «nuevo mundo» y por el choque cultural que produjo en quienes lo exploraron enfrentarse a una geografía tan distinta como la conocida hasta entonces, no porque al lector le interese conocer aspectos de la vida de Bernal Díaz del Castillo o de Alvar Núñez Cabeza de Vaca. Sucede lo mismo con, por ejemplo, los testimonios de quienes combatieron en la guerra, quienes sufrieron los devastadores efectos de los campos de concentración o quienes han sido víctimas de acontecimientos caracterizados por su elevado nivel simbólico, cuyo testimonio interesa en la medida en que da información sobre un suceso del que se quiere saber más.

Ahora bien, sucede que hay casos en los que confluyen el carácter público y ejemplarizante de una vida, el disfrute estético y el ansia de conocimiento sobre un determinado aspecto histórico. Y es que, durante la historia del siglo XX, son múltiples los casos de autores e intelectuales que, en su doble rol de víctimas de la violencia y la intolerancia y de portavoces ubicados en una posición de liderazgo y referencia en la sociedad, sintieron la vivencia de determinadas experiencias como un estímulo creador de doble objetivo. En primer lugar, su escritura nacía de la convicción de que no había que olvidar lo sucedido y, por tanto, había que dejar constancia del horror para poder incorporarlo a la memoria de futuras generaciones. En segundo, procedía de la obligación del escritor de no permanecer impasible ante la violencia y la injusticia - es decir, de su responsabilidad ante un pueblo que le consideraba autoridad-. Así fue manifestado, entre muchos otros, por Max Aub, al señalar irónicamente que el dictador Franco le había convertido en novelis$\mathrm{ta}^{46}$, obligándole a tomar partido ideológico y combatir con su literatura su interpretación de la historia; por George Orwell, quien explicó que la composición de Homenaje a Cataluña fue provocada por la necesidad de descubrir al mundo las persecuciones que el Partido Comunista estaba realizando en el seno del bando republicano durante la Guerra Civil Española; o por Alexander Solschenizyn, cuya obra posterior a 1960 está dirigida prácticamente en su totalidad a denunciar la barbarie del régimen estalinista, que él mismo sufrió al estar recluido durante varios años en un campo de concentración.

${ }^{46}$ Hasta 1936, la principal vocación literaria de Aub fue la escénica. Las dificultades que su condición de exiliado suponían para estrenar piezas dramáticas durante su estancia en México - motivadas por la desconfianza de los empresarios del país, que no quisieron arriesgar e invertir en montajes teatrales por miedo a que el desconocimiento de Aub en la sociedad mexicana, ignorante de su obra teatral anterior, llevase al fracaso los proyectos-, así como la obsesión memorialista del autor por relatar los horrores del franquismo, provocaron que desde 1939 su escritura de teatro disminuyese notablemente. 
Al aportar a los filtros de referencia a través de los que la memoria colectiva se forma una serie de conocimientos condenados de forma voluntaria y premeditada al olvido, la experiencia individual $-\mathrm{y}$, claro está, su transmisión a través de la escritura- puede convertirse en una forma de lucha contra las versiones oficiales de la historia y constituirse así como elemento al servicio del recuerdo de los pueblos y como instrumento con el que luchar para evitar la repetición de la barbarie pretérita. En su estudio El queso y los gusanos: el cosmos según un molinero del siglo XVI, Carlo Ginzburg expuso cómo el relato de las vidas individuales puede convertirse, de hecho, en una de las escasas formas de contrarrestar la formación de mentalidades dominantes desde el poder. Asimismo, demostró cómo, en ocasiones, la microhistoria que forma la peripecia intrahistórica de los ciudadanos anónimos puede convertirse en una «cultura subalterna y alternativa» capaz de oponerse a la establecida ${ }^{47}$.

Así, por ejemplo, durante las décadas posteriores al triunfo de la Revolución Rusa, el régimen totalitario soviético desarrolló una política de férreo control mediático destinada, entre otras cosas, a exaltar los logros revolucionarios, a silenciar el fracaso de algunas de sus políticas, a ocultar su fortísima actividad represora y a mantener la adhesión de los intelectuales que se habían sentido atraídos por los primeros cambios llevados a cabo tras los sucesos de octubre de 1917, percibidos en el mundo occidental como la materialización de todas las utopías libertarias. Una de las formas a través de las que se intentó cuestionar estas versiones oficiales impuestas desde el poder fue la publicación de forma sucesiva de una serie de libros de viajes de intelectuales que pasaron de estar seducidos ante el régimen comunista a criticarlo con vehemencia después de haberlo conocido tras desplazarse hasta la U.R.S.S. y comprobar la inexactitud de muchas de las informaciones difundidas desde los círculos oficiales.

Orient Express, Retorno a la U.R.S.S, Mi viaje a la Rusia sovietista o algunos pasajes de El mundo de ayer. Memorias de un europeo expusieron el impacto que el encuentro con la situación real de la sociedad soviética produjo en sus autores ${ }^{48}$ a través del doble descubrimiento que en ellas se muestra. Por una parte, el de la geografía — rural y urbana-, habitualmente idealizada, como todo el mundo oriental, por los autores occidentales y por otro, el de la ciudadanía rusa, cuya situación de desigualdad y miseria fue el germen que provocó el desengaño de los escritores que viajaron a Rusia en busca de la utopía socialista. La omnipresencia y el poder inmenso de Stalin, la creación de un complejo sistema de vigilancia policial que convertía a toda la ciudadanía en potencial sospechosa, el contraste entre la pobreza del pueblo y el lujo del que disfrutaban los gerifaltes del partido y la total falta de

${ }^{47}$ Vid. GINZBURG, Carlo. El queso y los gusanos: el cosmos según un molinero del siglo XVI. Madrid: Muchnick, 1994.

${ }^{48}$ De, respectivamente, John Dos Passos, André Gide, Fernando de los Ríos y Stefan Zweig.

Revista de Literatura, 2011, julio-diciembre, vol. LXXIII, n. ${ }^{\circ}$ 146, 379-406, ISSN: 0034-849X 
libertad, expresada en la persecución contra cualquier tipo de disidencia o en la imposición del realismo socialista como única forma artística válida fueron algunas de las críticas que estos escritores hicieron al régimen. Además de la profunda sensación de desencanto que se produjo en sus autores el haberse entregado a la causa comunista, haber visto en ella un sustento antiburgués contrario a la moral y a la sociedad imperantes y comprobar que en su puesta en práctica incurría en muchos de los defectos propios del sistema contra el que se rebelaban, estos casos muestran cómo el testimonio de la experiencia individual puede convertirse en voz alternativa contraria a la oficial. Y es que la literatura puede «hacer justicia» al dar voz a aquellos que jamás la tuvieron, puede restituir a quienes fueron deslegitimados o puede ayudar a comprender lo que sucedió. Como ha señalado María Teresa López de la Vieja, al recrear, partiendo muchas veces de vivencias personales, fenómenos marcados por el daño y el sufrimiento, la literatura cobra un «valor reflexivo» ${ }^{49}$. Los testimonios pueden dar voz a quien no la han tenido en la historia, y, al mismo tiempo, servir de memoria para quienes — voluntaria o involuntariamente- la han perdido.

La mera existencia del relato de las propias vivencias puede suponer así una forma de implicación que ayude a rellenar los vacíos que en la memoria colectiva, y por tanto en la identidad cultural de una sociedad, se han creado:

Las reliquias de una vida pasada, los restos de edificios, instrumentos, el contenido de los enterramientos, han sufrido la erosión de los vendavales del tiempo que han pasado por ellos; en cambio la tradición escrita, desde el momento en que se descifra y se lee, es tan espíritu puro que nos habla como si fuera actual. Por eso la capacidad de lectura, que es la de entenderse con lo escrito, es como un arte secreto, como un hechizo que nos ata y nos suelta. En él aparecen cancelados el espacio y el tiempo. El que sabe leer lo transmitido por escrito atestigua y realiza la pura actualidad del pasado ${ }^{50}$.

El «uso cognitivo» de los relatos puede vertebrarse de varias formas. Como ha defendido López de la Vieja, la literatura puede servir de complemento a la Filosofía Moral al proporcionarle ejemplos y casos prácticos que permitan hacer más duraderos e inteligibles sus abstractas conclusiones, creando así un «modelo de complementariedad» ${ }^{51}$ entre el goce estético y la reflexión moral que, no obstante, no logra romper la autonomía que existe entre las dos disciplinas, que impide que una obra de arte pueda ser juzgada exclusivamente por criterios éticos ${ }^{52}$. Todorov ha reclamado una crítica literaria que cuestio-

${ }^{49}$ LÓPEZ DE LA VIEJA, María Teresa. Op. cit., p. 14.

${ }^{50}$ GADAMER, Hans-Georg. Verdad y método. Salamanca: Sígueme, 1977, p. 216.

${ }^{51}$ LÓPEZ DE LA VIEJA, María Teresa. Op. cit., p. 23.

${ }^{52}$ Ya en las nociones de teoría literaria inscritas en la obra platónica se pueden encontrar conectados el modo de juzgar las obras y los valores que en ellas se transmiten, al afirmar el filósofo griego que «los discursos que son objeto de una enseñanza y se pronuncian para instruir, escribiéndose realmente en el alma, sobre la justicia, la belleza y bien, son los 
ne el valor moral de las obras, sobre todo cuando éstas estén basadas en fenómenos críticos para el desarrollo personal como la guerra, el exilio, la cercanía de la muerte o el paso por un campo de concentración. Según el autor franco-búlgaro, las obras no sólo han de ser juzgadas por sus valores literarios, sino también por su dimensión ética y humana. F. R. Leavis también ha puesto de manifiesto cómo las implicaciones morales e ideológicas de las obras han de ser tenidas en cuenta para su correcto análisis y valoración, al defender que las obras literarias no sólo han de ser juzgadas por su calidad estética, sino que su valía depende también de la capacidad con la que pueden llegar a sobrevivir y hacerse perdurables en ellas los valores humanos ${ }^{53}$.

En la medida que el relato de la propia experiencia puede contribuir a la formación de una memoria colectiva abierta y plural que dé cabida a diferentes interpretaciones de la realidad, la escritura autobiográfica puede suponer una acción. Con la narración de unos hechos habitualmente silenciados por los poderes se quiere dar voz a colectivos marginados y, al mismo tiempo, transmitir a la ciudadanía una versión del pasado reciente diferente a la oficial. Se asume así como tarea vital la defensa de la memoria de un tiempo condenado al olvido o a la deformación revisionista, formando una identidad grupal a través de testimonios

\section{EL TESTIMONIO COMO MEMORIA EJEMPLAR}

Tradicionalmente, se ha reconocido que la literatura podía desempeñar una función pedagógica que contribuyese al correcto funcionamiento de la socie$\mathrm{dad}^{54}$. Sobre esta consideración, válida hasta para las doctrinas inmanentistas, que defendían la autonomía del arte sin dejar de reconocer que, en ocasiones y sin que ello fuera condición esencial constitutiva, la belleza podía estar relacionada con la utilidad, reside el estudio del «saber narrativo» ${ }^{55}$. Ciertos relatos de carácter mítico y legendario, presentes en la historia de la literatu-

únicos que poseen eficacia y perfección y los únicos que merecen la pena» (Vid. WAHNÓN, Sultana. Introducción a la historia de las teorías literarias. Granada: Universidad de Granada, 1991, p. 249).

${ }^{53}$ Vid. SELDEN, Raman; WIDDOWSON, Peter; BROOKER. La teoría literaria contemporánea. Barcelona: Ariel, 2003, pp. 34-40.

${ }^{54}$ En la marco de la literatura española, por ejemplo, esa función estaría presente en textos fundacionales como las colecciones de cuentos del siglo XIII caracterizadas por su aspiración de ofrecer lecciones morales a los lectores. De hecho, los exempla contenidos en esos libros -que, en la mayoría de los casos, procedían de traducciones orientales- fueron frecuentemente utilizados por los predicadores. Sendebar o Calila e Dimna representarían algunos de estos hitos, cuya tradición y tono moralizante y didáctico fue continuada en el siglo XIV con la obra de Don Juan Manuel El Conde Lucanor.

${ }^{55}$ Vid. AGUIAR E SILVA, Vitor Manuel. Teoría de la literatura. Gredos: Madrid, 1972, pp. 42-108. 
ra prácticamente desde sus inicios, están capacitados para transmitir conocimientos a sus receptores. A través de ellos, se ha contribuido a la estabilidad de las instituciones, a la creación de modelos dignos de admiración y ejemplo o a la integración de los nuevos miembros de la sociedad. La propia estructura de estos cuentos demostraba su concepción como instrumentos al servicio de un conocimiento que facilitaría la convivencia social. Su prosodia y su estructura contribuían a su sencillo aprendizaje, posterior repetición y consiguiente perduración. Su consigna parecía ser la de «no olvidar», mantener vivo el relato para que éste pudiese desempeñar su función cognitiva y hacer partícipes de sus conocimientos a todos los miembros —incluidos los futuros ${ }^{56}$ - de la sociedad, como expresó Max Aub:

Posiblemente nuestra misión [la de los escritores] no vaya más allá que la de ciertos clérigos o amanuenses en los albores de las nacionalidades: dar cuenta de los sucesos y recoger cantares de gesta ${ }^{57}$.

Esa misma consigna puede estar presente en la funcionalidad de ciertos textos autobiográficos. Lo que se pretende con ellos no es ya el mantenimiento en la sociedad de un tipo de conocimiento práctico que fomente la estabilidad y el control de ésta, sino que «no se olviden» testimonios ni interpretaciones. En este caso, se entiende que la intención de recordar y hacer presentes en el discurso sobre el pasado a aquellos cuya voz fue negada por su condición de víctimas o perdedores responde a un imperativo moral ${ }^{58}$, pues la literatura estaría funcionando como si de un elemento complementario de la disciplina de la Ética se tratase al concretar, haciendo con ello más válidos y efectivos, los contenidos de sus postulados morales universales:

La información sobre situaciones densas, moral y políticamente densas, se encuentra bastante limitada por un conjunto de elementos. Resulta especialmente problemático el conocimiento de sucesos trágicos. En tales ocasiones, la Literatura cumple una función política y moral, al aportar conocimiento indirecto sobre formas de vida y sobre experiencias límite. En estos casos, la Literatura puede ser para la Filosofía un punto de partida para buscar más información y para reflexionar sobre experiencias — reales- que no han sido accesibles por los medios estándar (...). El punto de vista individual, las experiencias de los agentes pueden ser más relevantes y enseñar bastante más al lector que el punto de vista universal, en tercera persona ${ }^{59}$.

Al dotar de existencia a lo hasta entonces inexistente a través de la escritura, los autores estarían cumplimentando con su obra el uso ejemplar de la

\footnotetext{
${ }^{56}$ En ese sentido, resulta elocuente que Bertold Brecht titule «A los que nazcan más tarde» uno de los poemas en los que da cuenta de la violencia y la intolerancia que le tocó vivir en Alemania hitleriana durante la década de 1930.

57 AUB, Max. Hablo como hombre. Segorbe: Fundación Max Aub, 2002, p. 49.

${ }^{58}$ La concepción de la memoria como «deber ético» llevaría así aparejada la tesis de que olvidar equivale a someterse y obedecer.

${ }^{59}$ LÓPEZ DE LA VIEJA, María Teresa. Op. cit., p. 34.
} 
memoria que ha reclamado Todorov, adquiriendo un valor pedagógico y de advertencia. Para el teórico franco-búlgaro, tal instrumentación permite articular para el pasado un significado global que, más de allá de la concreción histórica, pueda tener validez en el presente ${ }^{60}$. La memoria puede ser, según esta interpretación, un instrumento pedagógico que ayude a las nuevas generaciones a no repetir los errores ya cometidos por sus antecesores ${ }^{61}$. Lo que se pretende con el uso ejemplar es transmitir un conocimiento suficiente del pasado como para poder extraer conclusiones de él válidas para la actualidad, puesto que «para que la colectividad pueda sacar provecho de la experiencia individual, debe reconocer lo que ésta puede tener en común con otras» ${ }^{62}$. El recuerdo tendría en esta aplicación de la memoria una dimensión universal, como ocurre también, por ejemplo, en los tribunales de los delitos contra la humanidad, cuya creación se basa en los mismos parámetros.

La literatura autobiográfica reconstruye experiencias concretas del pasado que pueden ser aplicadas a problemáticas del presente, dándoles con ello un sentido de universalidad y ejemplaridad. Para Gadamer, el proceso por el que se activa y se da utilidad al relato del pasado en el presente recibe el nombre de «fusión de horizontes» y se caracteriza por «la comprensión de la tradición abordada desde la situación presente del intérprete que se sitúa en la misma tradición, pero en una posición de distanciamiento que permite la introducción de una nueva perspectiva crítica» ${ }^{63}$. Se contribuye así a la identificación del lector con quien en principio le es extraño o ajeno «de tal manera de poder sentir su sufrimiento, su infelicidad o su desgracia como propios» ${ }^{64}$, pues, como dijo Elias Canetti, «sólo en su máxima desgracia podemos sentir a los demás hombres como a nosotros mismos» ${ }^{65}$. A través de

${ }^{60}$ Opuesto al uso ejemplar de la memoria existiría un uso literal, «uso literal de la memoria», basado en el enjuiciamiento e interpretación del presente con valores pretéritos, defendida por aquellos que consideran que determinados traumas históricos pueden perder su singularidad y gravedad si son puestos en relación con fenómenos históricos semejantes.

${ }^{61}$ Así, por ejemplo, en el testimonio sobre su experiencia en Auschwitz, Primo Levi insiste constantemente en la idea de que, ante la posibilidad de que un fenómeno como el nazi se repita - pues ha ocurrido una vez, y, por tanto, nada impide que vuelva a producirse-, es necesario dejar constancia del horror que supuso para concienciar y advertir a las nuevas generaciones. Del mismo modo, en Sin novedad en el frente, la novela testimonial de Erich M. Remarque sobre la I Guerra Mundial, se pone de manifiesto que la narración de los horrores provocados por el conflicto tendría sentido «si realmente llegara la paz, (...) algo por lo que valiera la pena haber vivido ese infierno» (LEVI, Primo. Op. cit., pp. 647652 y REMARQUE, Erich M. Sin novedad en el frente. Barcelona: Edhasa, 2005, p. 85).

${ }^{62}$ TODOROV, Tzvetan. Op. cit., p. 38.

${ }^{63}$ GADAMER, Hans-Georg. Op. cit., p. 377.

${ }^{64}$ PEREIRA, Gustavo; MODZELEWSKI, Helena. «Literatura y educación cívica». Razón práctica y asuntos públicos, 2008, $\mathrm{n}^{\circ}$ 9, [http://racionalidadpractica.blogspot.com/2008/ 08/literatura-y-educacin-cvica.html].

${ }^{65}$ CANETTI, Elias. «Prólogo». En Michichiko Hachiya. Diario de Hiroshima de un médico japonés (6 de agosto - 30 de septiembre de 1945). Barcelona: Turner, 2005, p. 8. 
la lectura se puede reconfigurar la identidad propia desde la experiencia contada en el relato de otro, tal y como ha señalado Joan-Carles Mèlich:

La lectura del texto transforma una subjetividad edificada sobre el principio de la libertad y de autonomía, y la [re]forma éticamente, es decir, sobre la responsabilidad y la heteronomía, porque son éstos los principios de la subjetividad como cuidado del otro (...). Lo que el yo es lo es en relación al otro. Se puede responder al otro y del otro. La identidad humana se forja en las respuestas que se le da al otro ${ }^{66}$.

Paradigmáticos ejemplos de la ejemplaridad que pueden tener los testimonios resultan, en el contexto de la literatura española, la declaración de intenciones que Manuel Andújar expuso en el prólogo de Saint Cyprien Plage. Campo de concentración, el texto en el que relató su periplo concentracionario — «[esta obra] sólo tendrá razón de ser si contagia o reaviva la esperanzada angustia que fue su motivo ${ }^{67}$ — o que Aub afirmase sobre las obras que escribió ambientadas en los campos en los que estuvo preso que fueron escritas para que la gente se diese cuenta de cuáles habían sido las dimensiones del tormento sufrido.

Gracias a su capacidad para reconstruir experiencias y hacer al lector sentirse en el lugar del otro, la experiencia individual adquiere un valor ético universal, como han puesto de manifiesto Richard Rorty — para quien sentimientos como la solidaridad surgen por «saber incluir en la esfera del 'nosotros' a personas inmensamente diferentes a nosotros mismo» ${ }^{68}$ - y Gustavo Pereira y Helena Modzelewski:

A través de la literatura se accede al más básico punto en común de todos los seres humanos: nuestra condición de seres libres e iguales. Obviando el color de la piel, la religión, la posición socio-económica, la literatura llega a conmover por medio de la manifestación de lo que compartimos como humanidad: los sentimientos, la conciencia, la razón. Por tanto, la literatura tiene como característica relevante para una ética global de reconocimiento recíproco el ser capaz de posibilitar el tránsito del extrañamiento al reconocimiento, al permitir acceder a través de la imaginación a la vida de otras personas que podían haber sido nosotros mismos ${ }^{69}$.

En semejantes términos se ha expresado Manuel Cruz, al afirmar que «si a alguna pertenencia parecemos abocados es a una pertenencia cada vez más abstracta, universal, y en todo caso será sobre esa base sobre la que habrá de

Semejante concepción remite a la interpretación mitridática del concepto aristotélico de catarsis, por la que se consideraba que el filósofo griego cifraba como función primordial de la literatura la presentación de la condición humana «como en un espejo brillante».

${ }^{66}$ MÉLICH, Joan Carles. La ausencia del testimonio. Ética y pedagogía en los relatos del Holocausto. Barcelona: Anthropos, 2001, p. 17.

${ }^{67}$ ANDÚJAR, Manuel. Saint Cyprien Plage. Campo de concentración. Huelva: Diputación de Huelva, 1990, p. 14.

${ }^{68}$ RORTY, Richard. Contingencia, ironía y solidaridad. Barcelona: Paidós, 1991, p. 60.

${ }^{69}$ PEREIRA, Gustavo; MODZELEWSKI, Helena. Loc. cit. 
establecer unos renovados vínculos fraternales [y] solidarios» ${ }^{70}$. Por eso Primo Levi (1998: 65) reconoció que su obra testimonial sobre su paso por los campos de concentración «podía ser interpretada como un testimonio universal de lo que el hombre es capaz de hacer a otro hombre» ${ }^{71}$, indicando cómo los hombres no sólo podían ser víctimas del horror y la barbarie, sino también causantes de ese mismo horror y esa misma barbarie.

George Steiner ha vinculado ese ideal de universalidad a la literatura que relata vidas de otros, al afirmar que «leer bien (...) es dejar vulnerable nuestra identidad, nuestra posesión de nosotros mismos» para pasar a sentir como propias vivencias y experimentaciones de otros gracias a los procesos de identificación:

Conjuramos la presencia, la voz del libro. Le permitimos la entrada, aunque no sin cautela, a nuestra más honda intimidad. Un gran poema, una novela clásica nos acometen; asaltan y ocupan las fortalezas de nuestra conciencia. (....) Quien haya leído La metamorfosis de Kafka y pueda mirarse impávido al espejo puede ser capaz, técnicamente, de leer la letra impresa, pero es un analfabeto en el único sentido que cuenta ${ }^{72}$.

Grosso modo, el concepto de «identificación» haría referencia a la actitud de un receptor al sentirse representado en la manera de pensar o de actuar de un personaje e imaginarse viviendo ese mismo papel. La teoría literaria, y en concreto la narratología, ha dedicado una extensa bibliografía a estudiar los mecanismos que operan para vertebrar las identificaciones del receptor durante el acto de lectura. De hecho, el concepto de «identificación» está presente en la historia de la reflexión crítica desde la obra aristotélica, en la que se alude a él con el nombre de «empatía». Para el filósofo griego, el comportamiento de los otros expresado en un discurso era capaz de ser asimilado por el receptor, «pues lo que le ocurre a otros parece que le puede ocurrir a uno mismo, porque, en general, es preciso definir que cuanto se teme para uno es lo que se compadece cuando ocurre a otros» ${ }^{73}$ (Aristóteles, 1971: 118).

Estrechamente vinculado al concepto de «identificación» estaría el de «punto de vista» — término análogo a los de «perspectiva»o «enfoque»—, con el que se hace referencia a la posición —entendida como cantidad de información disponible, capacidad de distanciamiento y relación con los elementos del relato, etc. - en la que se sitúa un narrador para contar una historia. Desde el clásico trabajo de Gerard Genette Figuras III, el estudio del punto de vista, al que el teórico francés aportó el término «focalización», distingue entre la actividad del narrador que relata los hechos con la de los personajes

\footnotetext{
${ }^{70}$ CRUZ, Manuel. Op. cit., p. 75.

${ }^{71}$ LEVI, Primo. Op. cit., p. 65.

${ }^{72}$ STEINER, Georges. Lenguaje y silencios: ensayos sobre la literatura, el lenguaje y lo inhumano. Barcelona: Gedisa, 1994, p. 32.

${ }^{73}$ ARISTÓTELES. Retórica. Madrid: Alianza, 1971, p. 118.
} 
desde cuya perspectiva los hechos son percibidos ${ }^{74}$. La combinación de ambas será la que guíe y gobierne la identificación de los lectores, determinada así tanto por la visión del mundo que el autor aporta al texto, por la actitud del narrador o por la actividad de los personajes como por la injerencia afectiva que se ejecuta en el proceso de interpretación. Hans Robert Hauss (1986) detalló los modelos de identificación que, según la interacción de los factores reseñados, podían producirse en la lectura: admiración y consiguiente deseo de emulación; compasión; emoción trágica ante el sufrimiento; indiferencia o pesar, y, por último, identificación asociativa para ponerse en el papel de todos los participantes ${ }^{75}$.

El Psicoanálisis ha contribuido también a desarrollar el concepto de «identificación» en la literatura, fundamentalmente gracias a las aportaciones de Jacques Lacan y a sus conclusiones sobre la analogía entre la adquisición de la propia identidad y el acto lector. Según la teoría psicoanalítica clásica, cuando un ser humano nace aún no es capaz de distinguir su identidad subjetiva de la alteridad que le rodea. A través de la denominada «fase del espejo», producida en los primeros meses de vida, los individuos comienzan a tomar conciencia de sí mismos, siendo capaces de reconocerse y de descubrirse a sí mismos como algo diferente de los otros. Ese proceso es conocido como el de la «identificación primaria» que, complementada con las posteriores «identificaciones secundarias»—que, provenientes de crisis, traumas y deseos, llevan al individuo a identificarse en sus primeros años de vida con quienes le rodean-, conforma la personalidad del sujeto. Para Lacan, este proceso presenta diversas concomitancias con la lectura, convertida así en un dispositivo capaz de reproducir una fase determinante en la formación del yo. Del mismo modo que el ser humano al nacer toma conciencia de sí mismo al ver su imagen en el espejo y ser capaz de distinguirla de la de los demás, el lector puede proyectar su propia identidad en el texto a través de una operación intelectual que le lleva a verse reflejado en un yo intratextual. De hecho, para Lacan la comunicación sólo es posible y efectiva si se acepta la reversibilidad del sujeto y su posibilidad de reconocerse en el otro $^{76}$.

\section{EL TESTIMONIO HISTÓRICO}

Para dar cuenta de los acontecimientos traumáticos, diversos autores han defendido la existencia de un nuevo modelo de escritura autobiográfica que, susceptible de ser presentado tanto bajo alguna de las categorías clasificadas por

\footnotetext{
${ }^{74}$ Vid. GENETTE, Gerard. Figuras III. Barcelona: Lumen, 1994.

${ }^{75}$ Vid. HAUSS, Hans Robert. Experiencia estética y hermeneútica literaria. Madrid: Taurus, 1986.

${ }^{76}$ Vid. LACAN, Jacques. El seminario II: El yo en la teoría de Freud y en la técnica psicoanalítica. Barcelona: Paidós, 1983.
} 
Manuel Alberca como «novelas del yo»-y que, grosso modo, tendrían como principal característica la transmisión de experiencias a través de primas de escritura ficcional ${ }^{77}$ o bajo el tradicional relato autobiográfico, tendría como principal señal de identidad ser un discurso cuyos objetivos no se limitarían a la información de los hechos, sino que también incluirían la evocación de las sensaciones que la crueldad y el dramatismo de lo vivido provocaron en el sujeto creador. Renaud Dulon, uno de los autores que ha defendido la existencia de un género específico en los relatos testimoniales de los acontecimientos traumáticos, denomina a esta nueva tipología de textos «testimonio histórico» y la distingue de lo que él mismo llama «testimonio ordinario»:

Lo que he propuesto en llamar testimonio ordinario es lo que damos y recibimos en las relaciones ordinarias; este testimonio ordinario constituye, por ejemplo, la base del testimonio judicial en los procesos penales. La neutralidad exigida del testigo judicial obliga a que su declaración se atenga a los hechos, que evite cualquier juicio sobre las personas e incluso que se calle sus reacciones. Ahora bien, eso no es del todo lo que esperamos del testigo en una relación cotidiana. Si uno de sus prójimos le informa de que ha asistido a un terrible accidente de tráfico, usted no le pide que mencione la disposición de los cuerpos o el color de los vehículos. Por el contrario, usted espera que exprese la conmoción que sintió ante ese espectáculo, que él le haga partícipe de su emoción y él, por su parte, espera que usted se haga eco de sus sentimientos, con un juicio moral sobre la inseguridad viaria, por ejemplo ${ }^{78}$.

Más que en la clásica oposición entre subjetivismo y objetivismo — pues todo testimonio, en cuanto que parte de un sujeto, carece de una total objetividad-, la diferencia entre los dos tipos de testimonios expuestos parece estar en la inclusión en uno de ellos de un componente afectivo que busca la empatía con el público lector. Así, este texto vivencial tendría evidentes diferencias a nivel pragmático con el resto de categorías basadas en el pacto autobiográfico, pues buscaría conseguir una reacción entre los lectores:

[El] testimonio histórico es este fenómeno contemporáneo: supervivientes de las tragedias masivas publican para el gran público lo que ellos han vivido, a veces para denunciar tal o cual responsabilidad, más frecuentemente para recordar a los desaparecidos, y siempre para que los ciudadanos tomen conciencia de lo que ha pasado y se movilicen contra el regreso de la barbarie ${ }^{79}$.

Los testimonios históricos tienen como objetivo convertirse en ejercicios a favor de la memoria ejemplar, intentando suscitar en los ciudadanos una reacción de impacto a través de la especificación de los horrores que sus autores han tenido que vivir. Se pretende que el infierno personal relatado se

77 Vid. ALBERCA, Manuel. El pacto ambiguo: de la novela autobiográfica a la autoficción. Madrid: Biblioteca Nueva, 2007.

78 DULONG, Renaud. «La implicación de la sensibilidad corporal en el testimonio histórico». Revista de Antropología Social, 2004, n. ${ }^{\circ}$ 13, p. 104.

${ }^{79}$ Ibid., p. 98. 
convierta en material para la reflexión de los lectores y adquiera, por tanto, dimensiones de universalidad que le hagan trascender las coordenadas espaciales y temporales en las que se produjo y que le permitan convertirse en paradigma condenatorio aplicable a cualquier manifestación histórica similar.

Para que el testimonio histórico desarrolle este rol ejemplar y pueda hacer que quien lo lea interiorice que acontecimientos análogos no pueden volver a suceder es necesario que transmita con la máxima intensidad posible la violencia sufrida. La escritura se encuentra aquí con un doble problema. Por un lado, el hecho de que, a diferencia de las artes visuales, no dispone de la fuerza emotiva y de la capacidad de impacto instantáneo de la imagen. Por otro, la existencia de determinados niveles de horror y violencia - muchos de los cuales fueron experimentados por primera vez a lo largo del siglo XX y de los convulsos sucesos que jalonaron su desarrollo en el mundo occidental- tan inconmensurables como desconocidos para el ser humano, incapaz de transmitir con palabras convencionales una realidad que se puede experimentar pero no conceptuar.

Jean Norton Cru (1993), excombatiente de la I Guerra Mundial, fue uno de los primeros teóricos en reclamar un análisis diferencial de los testimonios históricos ${ }^{80}$. Para él, la categoría de «sujeto-histórico» no sólo hacía referencia al contrato implícito establecido entre autor y lector para narrar acontecimientos reales —o sometidos, al menos, a la percepción que el primero tuvo sobre ellos-, sino también y sobre todo a la dimensión pragmática otorgada por el rol de testigo del autor. En un trabajo centrado en las obras testimoniales sobre la guerra que asoló Europa entre 1914 y 1918 —en la que por primera vez en la historia se utilizaron armas de destrucción masiva y la población civil se convirtió en potencial objetivo de las estrategias militares de combate-, Norton Cru señaló que los únicos testimonios válidos sobre la experiencia bélica eran los de los propios combatientes. Las versiones oficiales convirtieron la información sobre el conflicto en una continua exaltación patriótica: mintieron a la opinión pública, ocultaron el verdadero - y elevadísimo- número de muertos, distorsionaron el auténtico desarrollo del conflicto, etc. De este modo, los testimonios de quienes habían participado en la guerra - y, por tanto, habían conocido de primera mano su evolución y características - se convirtieron en una de las escasas formas de resistencia ante el engaño con el que se quería someter a las sociedades ${ }^{81}$. Jean Norton Cru

${ }^{80}$ Vid. NORTON CRU, Jean. Témoins. Nancy: Presses Universitaires, 1993.

${ }^{81}$ Análoga situación aconteció en España durante la Guerra de Marruecos. Frente al mensaje oficialista transmitido desde el poder, quienes participaron en el conflicto y dejaron testimonio de su experiencia insistieron en dramática realidad vivida en las trincheras africanas. Así, Arturo Barea señaló que La ruta, su obra testimonial sobre el conflicto, era «parte de la tradición nunca escrita» y que se distinguía «de los libros históricos [, que] dan lo que se llama los hechos históricos», al tiempo que dejaba claro que la guerra que él vivió «no tenía semejanza alguna con la guerra y con el desastre que (...) [los] periódicos españoles desarrollaban 
negó cualquier tipo de validez como testimonio histórico tanto a las obras que no respondían a la verdad de lo sucedido - bien por la falta o el carácter erróneo de la información, bien por el uso de estereotipos relacionados con la experiencia bélica y su expresión artística- como a aquellas incapaces de transmitir con exactitud las reacciones personales que provoca estar inmerso en un acontecimiento infernal como una guerra. La importancia de lo sentido al vivir una experiencia traumática llevó a Norton Cru a distinguir entre lo que él denominó el «primer testimonio», caracterizado por su inmediatez y emanado directamente de las vivencias, y el surgido después de la reflexión. Para el autor francés, por tanto, no podría darse el mismo valor al testimonio que surge de forma espontánea con el que es reformulado o reconstruido bajo parámetros artísticos.

Excesivamente radicales en algunos aspectos, como en su negativa a dar validez a cualquier obra no compuesta por un testigo, los planteamientos y las conclusiones de Norton Cru permiten, en cualquier caso, establecer un hito histórico fundamental en el análisis de las relaciones entre literatura y acontecimientos traumáticos al reclamar la necesidad de estudiar desde prismas diferenciales la literatura escrita por testigos del resto de obras.

Si las conclusiones de Norton Cru sobre la importancia de la concisión de testigo son puestas en relación con la necesidad de que el receptor de los textos autobiográficos admita que lo que se le está relatando es veraz, surge de manera inmediata la pregunta de por qué alguien puede aceptar que lo que está leyendo es cierto, y, por tanto, que el autor es verdaderamente el testigo que dice ser. Toda vez que se admite que no hay ningún rasgo que permita diferenciar formalmente los textos autobiográficos de los ficcionales, parece que la confianza en el compromiso del autor es el único criterio capaz de generar los pactos autobiográfico y de veracidad. La necesidad de tener que admitir lo dicho por el autor sin cuestionamientos ha llevado a Cordón a afirmar que «más importante que el argumento del pacto [de veracidad] es el de autoridad» $»^{82}$. Más que por la apariencia de verdad que pueda tener lo relatado, los

ante los ojos del lector». Por su parte, José Díaz Fernández —autor de El blocao—y Ramón J. Sender - que compuso Imán con su experiencia en África como base-incidieron en la diferencia que existía entre el modelo épico con el que se identificaba a los soldados que permanecían en Marruecos y la cruda realidad con la que habían de convivir. Mientras que el primero afirmaba no recordar «ningún episodio heroico» de su estancia en la guerra, el segundo mostró la trágica ironía que suponía ensalzar como modelos a seguir a quienes vivían en condiciones infrahumanas: «Nosotros somos lo que en la prensa y las escuelas llaman héroes: llevar sesos de un compañero en la alpargata, criar piojos y beber orines, eso es ser héroes. Yo soy un héroe». (BAREA, Arturo. La ruta [La forja de un rebelde II]. Madrid: Bibliotex, 2001, pp. 112 y 145; DÍAZ FERNÁNDEZ, José. El blocao. Madrid: Viamonte, 1998, p. 51; SENDER, Ramón J. Imán. Barcelona: Destino, 1998, p. 136).

${ }^{82}$ CORDÓN, José Antonio. «La información biográfica: sobre la memoria y sus representaciones». Boletín de ANABAD (Asociación Nacional de Archiveros, Bibliotecarios, Museólogos y Documentalistas), 1997, n. ${ }^{\circ}$ 1, p. 118. 
lectores toman los diferentes discursos autobiográficos como ciertos por el respeto que mantienen hacia la letra escrita, erigida en factor de confianza básica en la transmisión social del conocimiento.

La capacidad para que el relato de la propia experiencia sea tomado como verdadero y, por tanto, como referente capaz de convertirse en un ejercicio de memoria ejemplar a través del que alumbrar episodios del pasado ha sido explicado a través de diversas teorías en las que se analiza la transformación de la voz escrita en autoridad. Entre ellas, destacan las de Paul Benichou, Jürgen Habermas y Pierre Bourdieu. Según el primero, a partir del siglo XVIII y gracias al desarrollo de los medios técnicos, la ampliación del público lector por los procesos de alfabetización y culturización y la progresiva adquisición de independencia del escritor frente al poder han provocado que sea «la literatura, con las ideas y valores que acredita en un radio social cada vez mayor, (...) responsable, en una parte nada desdeñable, del destino de la humanidad» ${ }^{83}$ (Benichou, 2001: 440). Desde hace tres siglos, los cambios sufridos en el rol social del escritor y, sobre todo, en su forma de relacionarse con su contexto, en especial con el público y con las fuentes de poder, han provocado no sólo el ascenso social de los hombres de letras, sino también el desarrollo de una «autoridad laica» que, de forma progresiva, ha podido consolidarse frente a las autoridades tradicionales —eclesiástica y gubernamental- Con el advenimiento de esa nueva autoridad, los escritores han tomado, a través de su dimensión pública y, sobre todo, a través de las repercusiones de sus obras, un importante papel en la construcción de la amalgama de discursos que forjan la memoria colectiva de los pueblos y, con ello, su particular imaginario. Especialmente interesantes han sido sus aportaciones en aquellos casos en los que su interpretación ha diferido de la impuesta desde el poder, logrando con ello dar nuevas visiones del presente y nuevos marcos de referencia para construir la memoria colectiva de las sociedades.

Habermas, por su parte, identificó el proceso de adquisición de autoridad de los escritores con la consolidación de la esfera pública. Para el filósofo alemán, la creación de un espacio abierto de discusión racional sobre asuntos de interés público coincide con la capacidad de quienes participan en él de «sustraerse a la influencia del Estado y [poder ser] crítico con respecto a los actos o fundamentos de éste» ${ }^{84}$. La autonomía y capacidad del escritor de mostrar su disonancia con las versiones oficiales transmitidas desde el poder estaría, por lo tanto, intrínsecamente relacionada con la creación del ámbito de debate al que alude Habermas.

\footnotetext{
${ }^{83}$ BENICHOU, Paul. La consagración del escritor (1750-1830). México D. F.: Fondo de Cultura Económica, 1981, p. 440.

${ }^{84}$ HABERMAS, Jürgen. Historia y crítica de la opinión pública. Barcelona: Gili y Gaya, 2002, p. 177.
} 
Según Pierre Bourdieu, la posibilidad de que el relato de una experiencia pueda convertirse en autoridad y, por tanto, elemento al servicio de la construcción -o el cuestionamiento- de los filtros que condicionan la memoria colectiva de las sociedades no reside tanto en el valor del propio texto centrado en los recuerdos como en el de su creador. Para explicar el reconocimiento que la sociedad puede mostrar hacia un escritor, el autor francés acuñó el término «capital simbólico», definido como la «propiedad cualquiera que, percibida por unos agentes sociales dotados de las categorías de percepción y de valoración que permiten percibirla, conocerla y reconocerla, se vuelve simbólicamente eficiente, como una verdadera fuerza mágica» ${ }^{85}$. Su existencia - fundamental para explicar la teoría del autor francés, que defiende que el espacio social se define por la coexistencia de diversos poderes que influyen, según la fuerza del capital de sus miembros, en diversos campos- pone de manifiesto que «el productor de valor de la obra de arte no es el artista, sino el campo de producción como universo de creencia que produce el valor de la obra de arte como fetiche al producir la creencia en el poder creador del artista ${ }^{86}$. Por tanto, los efectos de los textos literarios no dependen de su esencia artística o del valor de su creador, sino de la cantidad de capital de que éste disponga, que es, al fin y al cabo, la que le permite influir en uno de los campos del espacio social —en este caso, el literario e intelectual-. Para Bourdieu, el proceso por el que los escritores buscaron su independencia y autonomía respecto a los poderes públicos — consolidado en el siglo XIX a través de casos emblemáticos como el de Zola y el «caso Dreyfuss»- determinó su capacidad de poder disponer de su capital simbólico dentro de su propio campo, legitimando con ello su capacidad para revestir su testimonio de la autoridad suficiente para poder ser incorporado a la memoria de las sociedades. La progresiva adquisición de prestigio y autoridad por parte de los autores permitió que lo que antaño eran simples escritores pasaran a convertirse en intelectuales capaces de intervenir en la vida pública con unos instrumentos que, por definición, no pertenecen al campo político sino al literario.

\section{A MODO DE CONCLUSIÓN: EL VALOR UNIVERSAL DE LA ESCRITURA PERSONAL}

Teniendo en cuenta que la escritura es la forma más habitual de materialización y transmisión del recuerdo y que la memoria colectiva se nutre de diversas interpretaciones individuales del pasado, parece lógico pensar que la literatura autobiográfica y la creación de ficciones a partir de la propia experiencia pueden servir en ocasiones de instrumento contra el olvido. Al mis-

\footnotetext{
${ }^{85}$ BOURDIEU, Pierre. Las reglas del arte. Barcelona: Anagrama, 2005, p. 171.

${ }^{86}$ Ibid., p. 339.
} 
mo tiempo, pueden ser herramientas a favor del conocimiento, pues en toda configuración hay una realidad sepultada que, en ocasiones, sólo los testimonios individuales son capaces de transmitir. Pueden convertirse en la única fuente de información y, por extensión, de actuación frente a lo sucedido, ya que en determinadas ocasiones históricas «el lenguaje se considera el más válido instrumento al servicio de la acción social» ${ }^{87}$. De ahí que reflexionar sobre lo vivido trascienda en ocasiones la mera condición de capacidad y se convierta en una obligación para con la sociedad y en un compromiso con la verdad que se intenta ocultar. Según Anita Rupprecht, «la autobiografía puede llegar a transformarse en un elemento necesario para la cultura, la política y la memoria de una sociedad» ${ }^{88}$. Así se explica que, en determinados ámbitos, ser víctima, testigo y superviviente sea suficiente legitimación para alzar la voz y contar lo vivido, convirtiendo el testimonio personal en un documento de valor universal capaz de iluminar determinados aspectos de la historia tradicionalmente condenados al olvido o a la deformación.

Fecha de recepción: 26 de febrero de 2009

Fecha de aceptación: 15 de octubre de 2009

${ }^{87}$ UGARTE, Michael. Literatura española en el exilio: un estudio comparativo. Madrid: Siglo XXI, 1999, p. 20.

${ }^{88}$ RUPPRECHT, Anita. «Making the difference: postcolonial theory and the politics of memory». En Campbell, Jan; Harbord, Janet (eds.). Temporalities, autobiography and everyday life. Manchester: Manchester University Press, 2002, p. 50. 